\title{
Effective application of the APQP quality tool in Pull Back Car toy assembly processes
}

\section{Aplicación efectiva de la herramienta de calidad APQP, en procesos de emsamble de juguetes Pull Back Car}

\author{
BONES-MARTINEZ, Rosalia†*, SOTO-LEYVA, Yasmin and SANTOS-OSORIO, Arturo \\ Tecnológico Nacional de México / Instituto Tecnológico Superior de Huauchinango, Mexico. \\ ID 1 ${ }^{\text {st }}$ Author: Rosalia, Bones-Martínez / ORC ID: 0000-0001-8829-9737, CVU CONACYT ID: 368744 \\ ID $1^{\text {st }}$ Co-author: Yasmin, Soto-Leyva / ORC ID: 0000-0003-2652-7065, CVU CONACYT ID: 951464 \\ ID $2^{\text {nd }}$ Co-author: Arturo, Santos-Osorio / ORC ID: 0000-0003-3643-5770, CVU CONACYT ID: 951024
}

DOI: $10.35429 / \mathrm{JIO} .2020 .7 .4 .24 .31$

Received July 25, 2020; Accepted December 30, 2020

\begin{abstract}
The current Mexican market for the production and assembly of toys (Pull back car) demands ever higher productivity, quality, cost and delivery rates, complying with defined production requirements, as the market is becoming larger and of course competitive. For their part, companies have the need to continually launch new models to stay competitive. The current procedure is based on project management through a recognized procedure in the sector, such as APQP (Advanced Product Quality Planning), based on the implementation of a series of key management tools for DNP. The research carried out characterized the current context of toys for the development of new parts in the local toy sector of the Meccano company, in the Huauchinango Puebla region. An operational model proposal is made for the Pull back car toy assemblers, in order to improve performance in the activities of the Meccano company.
\end{abstract}

\begin{abstract}
Resumen
El mercado mexicano actual de producción y ensamble de juguetes (Pull back car) demandas índices de productividad, calidad, costo y entregas cada vez mayores, cumpliendo con requisitos de producción definidos, ya que el mercado cada vez se hace más grande y por supuesto competitivo. Por su parte, las empresas tienen la necesidad de lanzar continuamente nuevos modelos para mantenerse competitivas. El procedimiento actual se basa en la gestión de proyectos a través de un procedimiento reconocido en el sector, como el APQP (Planeación Avanzada de la Calidad del Producto), basado en la implementación de una serie de herramientas clave de gestión para el DNP. En la investigación realizada, se caracterizó el contexto actual de los juguetes de desarrollo de nuevas partes en el sector local de juguetes de la empresa Meccano, en la región de Huauchinango Puebla. Se realiza una propuesta de modelo operacional para las ensambladoras del juguete Pull back car, con el fin de mejorar el desempeño en las actividades de la empresa Meccano.
\end{abstract}

Citation: BONES-MARTINEZ, Rosalia, SOTO-LEYVA, Yasmin and SANTOS-OSORIO, Arturo. Effective application of the APQP quality tool in Pull Back Car toy assembly processes. RINOE Journal-Industrial Organization. 2020. 4-7:24-31.

\footnotetext{
*Correspondence to Author (Email: rosalia@ huauchinango.tecnm.mx)

$\dagger$ Researcher contributing first author.
} 


\section{Introduction}

Over the years the design and development of new products has been a key element for the survival of any company in the market. Currently it is vital that the product meets the needs of the client, to ensure its acquisition again.

In the automotive industry the integration of any car model is very expensive and requires large investments usually; In addition, the market is very competitive, which is why it requires good quality in its products and it cannot afford to deliver defective products to its customers, since in various circumstances the products imply the requirement of zero defects against specifications, since its use involves the risk of human lives; Due to the aforementioned, the industries were forced to create a methodology with which they could ensure the quality of their products, it was then that the automotive industries, including FORD, DIME CHRYSLER, GMC (General Motors Company $)^{1}$, created a standard called QS-9000, with which they could observe the quality of the product, within this a section called APQP (Advanced Planning Quality Product) or Advanced Planning of Product Quality was generated, where this guide is carried out the development of a new product in this case automobiles.

The application of APQP has been shown to have high impact by expanding the ability of organizations to develop and produce products and systems that meet customer needs. Therefore, it could be profitable in small and medium-sized companies, without the need to seek the implementation of a QMS (Quality Management System) of the ISO-9001: 2000 type. It is obvious that we encourage work in the direction of SGC, but we urge to take better advantage of one of the quality technologies with the greatest impact.

The objective of this article is to present the most important aspects of advanced product quality planning, in relation to Pull back car assembly, as well as to show the results obtained in each of the phases of the APQP, analyzed.

\footnotetext{
${ }^{1}$ It is the name given to the automotive industry quality system requirements that were developed by Chrysler, Ford, General Motors, and major truck manufacturers and published in late 1994.
}

The practical case has been structured as follows: In section one the description of the concepts of the APQP methodology is presented, in section 2 the essential elements for the development of APQP in the company where the study is applied are presented. and an analysis of the prevailing practices in terms of product quality planning, that is; where a market investigation will be carried out in order to know and evaluate the experience of the team and ending with a quality assurance plan, knowing the defects that exist in both the product and the process; and in this way ensure that, before delivering a product to the client for the first time, the correct methodology is followed and the necessary quality controls are established to provide a quality product, on time and at the lowest cost.

In section three, there are the results of the application, finally in the last sections are the conclusions and references, managing to highlight the positive points, exposing the conclusions of the project and the recommendations that could be functional for continuous improvement and support the supporting information used in the application.

\section{Methodology to be developed}

This section will present selected and important information that must be taken into account to develop the phases of the APQP methodology. Each phase is made up of a series of specific tasks.

Leaving aside the particularities of each company and project, and based on the APQP procedure, every automotive development project will follow a cascade planning (phasegate process) similar to that represented in Figure 1 Diagram of advanced planning of the $\mathrm{APQP}$ product quality. 


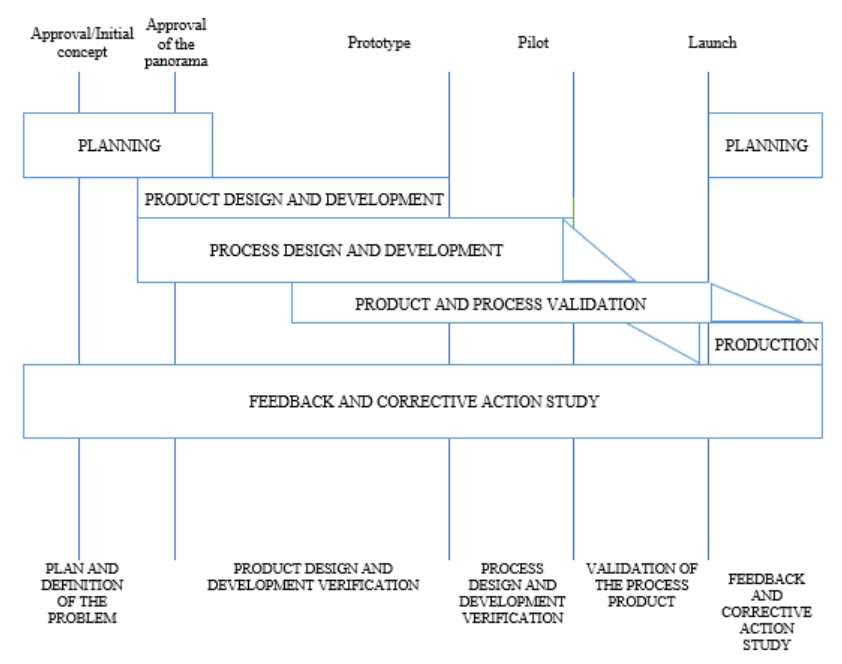

Figure 1 APQP Advanced Product Quality Planning Diagram

Source: Chrysler, et al., (2008)

Each of the APQP stages are described below, defined in the Reference Manual created by the AIAG (Automotive Industry Action Group), in order to determine the standards for automobile manufacturers and parts suppliers.

\section{Stage I: Planning and definition of the program}

In this study phase, the objective sought by the program is defined, which will allow planning. Taking into consideration that at this stage the customer's need is indicated with respect to the product to be manufactured. For this, all the relevant information regarding the product offer is gathered, this through meetings with the client.

In this way, a market research is carried out, which allows defining in quantitative data the need, acceptance and opinion of potential customers in relation to the product to offer.

\section{Stage II: Product Design and Development}

Once the client's need has been determined and quantified, this phase is directed to the development of the product, that is, to define its characteristics based on the established requirements and in this way carry out the designs and monitoring of the final product to be offered. CAD software will be used for the design of this, for the purposes of this study AutoCAD software was used, this being a software that adapts to the specifications that are sought with the project. In tune, evaluations are carried out to measure the conformity of the design with respect to the initial requirements.

\section{Stage III: Design and development of the process}

Defined the design of the final product, this stage aims to develop a manufacturing system to achieve quality products. The development of process flow diagrams is considered, as well as the inclusion of formats, Process FMEA, the creation of a pre-launch Control Plan, all of them aimed at finding the best conditions for the production of the selected design.

\section{Stage IV: Product and process validation}

A production control plan is carried out, which allows the evaluation of the process and the product. To do this, the application of operations research tools, such as: The Master Production Plan (MPS), Bill of Materials or Material Boom and the Material Requirement Plan (MRP).

\section{Stage V: Feedback, evaluation and corrective actions}

The objective is to evaluate the effectiveness of the product quality planning effort and analyze the manufacturing process when all common and special causes of variation are present.

\section{Results}

Below are the results obtained by each stage of implementation:

\section{Stage I: Planning and definition of the program}

In the first instance, a questionnaire is carried out that allows us to determine the attributes that people look for in a toy, so that it is considered as quality. The analysis of three of the questions with the greatest impact and importance in the study is indicated.

Emphasizing the main characteristics that the client looks for in a toy in order to acquire it, three alternatives are identified: the price, the popularity derived from its diffusion in the media, and also the educational component. 
The responses can be viewed in Figure 2 Attribute at the time of purchase, and as noted, the attribute with the highest percentage of choice corresponds to the popularity of the toy with $44 \%$ of the total surveys, followed by the price with $34 \%$, this It is relevant since it allows us to recognize the importance of the product design being innovative and attracting the attention of customers if it is made known in the media, and we must also ensure that the price of this is accessible.

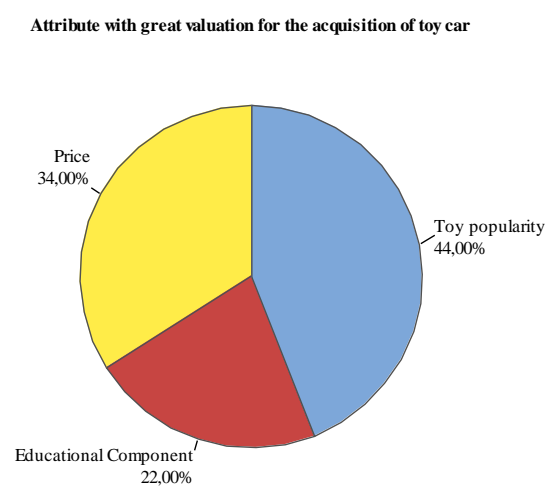

Figure 2 Attribute at the time of purchase Source: Own elaboration, (2020)

Now, while identifying the sales channel that is going to be used, a question was asked regarding the form of purchase, in which the results show us (See Figure 3 Form of purchase) that $73 \%$ of people choose to buy from through online sites, while only $27 \%$ do so directly in sales establishments. This data allows us to recognize that emphasis should be placed on the form of online sales, which also means that a procedure and form of evaluation for online customer service must be general. In turn, the power to determine the delivery strategies of the final product.

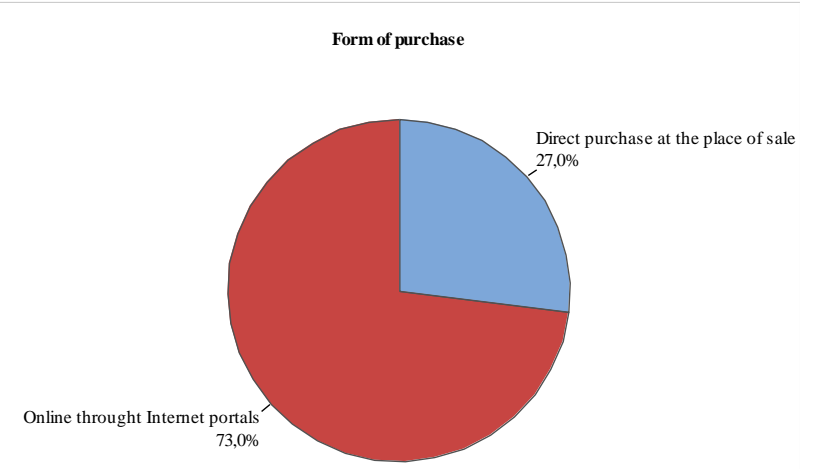

Figure 3 Form of purchase

Source: Own elaboration, (2020)
Finally, identify the reason for buying this with the intention of determining how the forecast will be, and if it follows a seasonal behavior. We can see in Figure 4 Reason for purchase that the main reason for purchase according to respondents with $67 \%$ to purchase is a birthday or special occasion gift. Followed by the purchase because it is a festive date like Christmas, while only $12 \%$ say they buy a toy for other reasons.

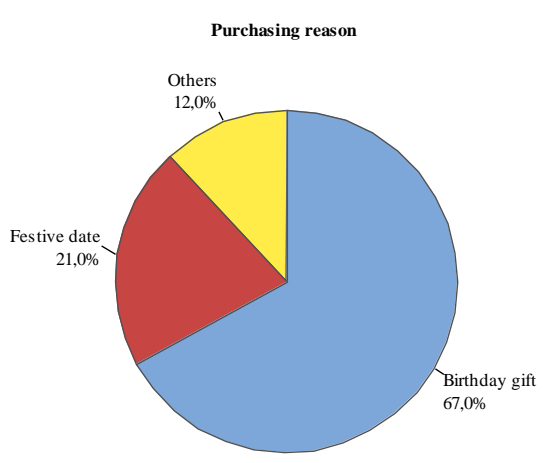

Figure 4 Purchasing reason Source: Own elaboration, (2020)

\section{Stage II: Product Design and Development}

The parts that will make up the toy car (Pull Back Car) are determined, for this we use a format that allows us to identify their quantitative and qualitative attributes, as seen in Figure 5 Characteristics of Pull back assembly parts car.

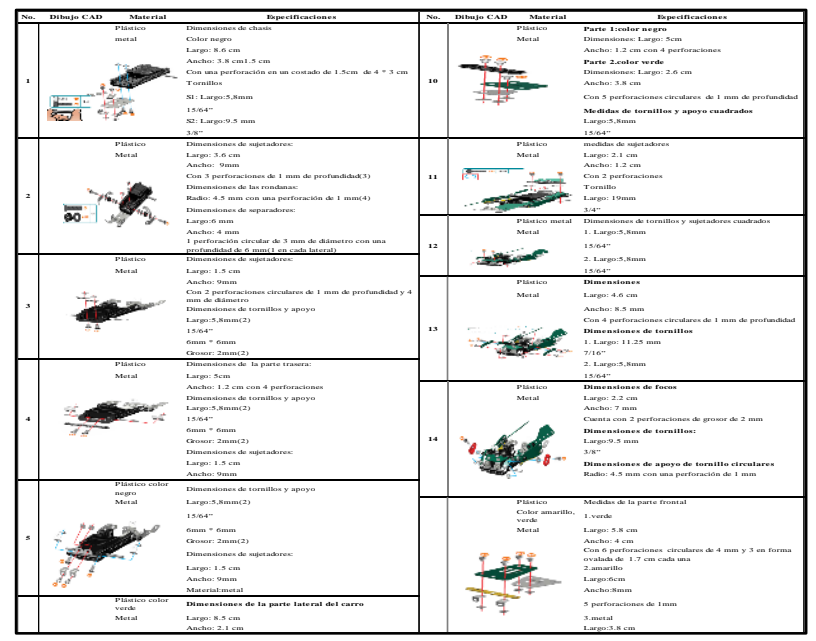

Figure 5 Pull back car assembly parts features Source: Own elaboration, (2020)

Next, drawings are made in the AutoCAD software to identify the assembly of the parts that make it up, thus resulting in the design of the final prototype. (Figure 6 Final product made in CAD).

BONES-MARTINEZ, Rosalia, SOTO-LEYVA, Yasmin and SANTOS-OSORIO, Arturo. Effective application of the APQP quality tool in Pull Back Car toy assembly processes. RINOE Journal-Industrial Organization. 2020 

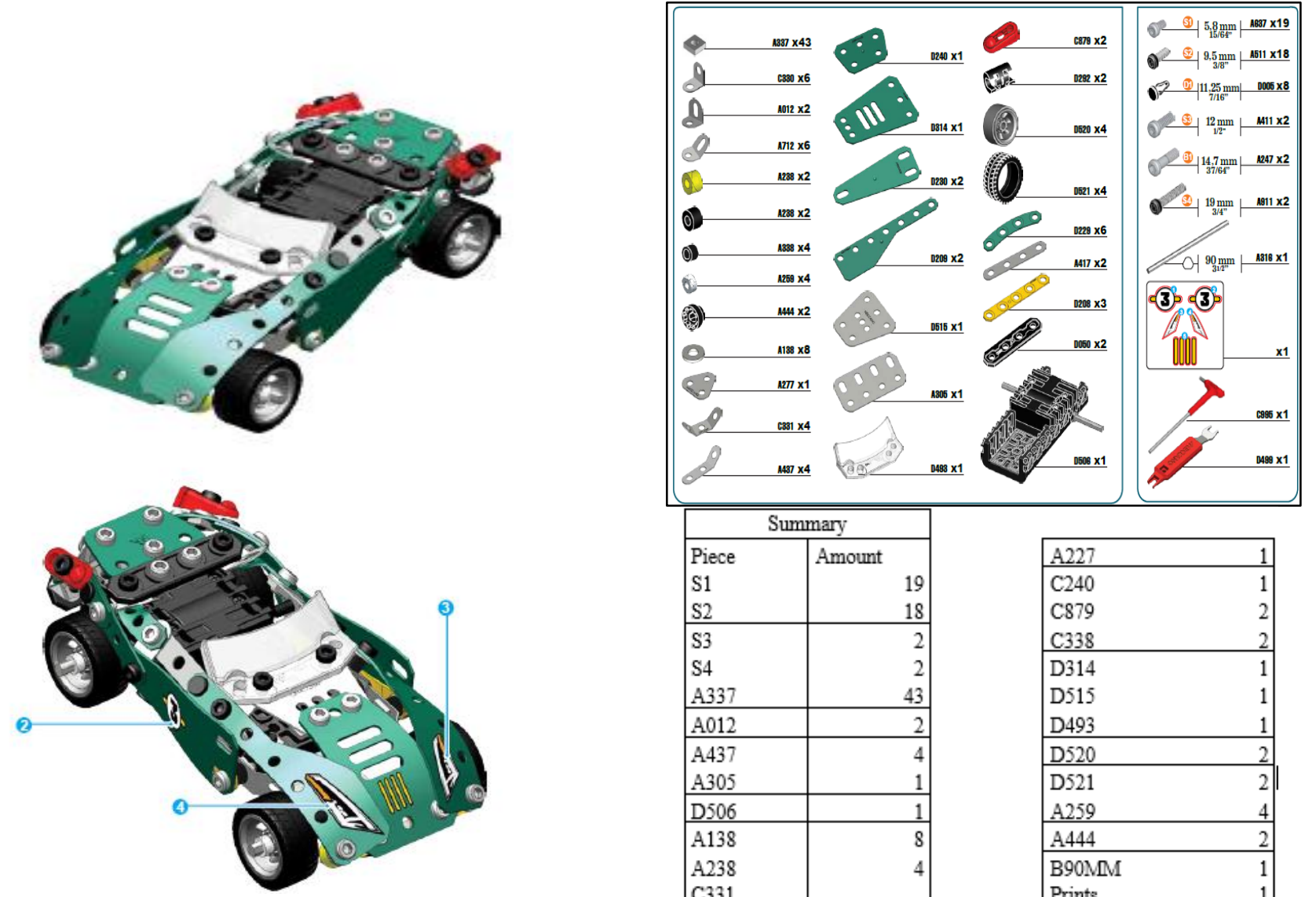

Figure 6 Final product made in CAD

Source: Own elaboration, (2020)

\section{Stage III: Design and development of the process}

Information is collected regarding the properties of the materials of each piece that makes up the final product. The quantity necessary for the assembly of the pieces is identified, as well as the duration in years. This in addition to the bill of materials (Figure 7 Preliminary bill of materials).

\begin{tabular}{|c|c|c|c|}
\hline \multicolumn{2}{|c|}{ Summary } & & \\
\hline Piece & Amount & A 227 & 1 \\
\hline S1 & 19 & $\mathrm{C} 240$ & 1 \\
\hline S2 & 18 & $\cos 79$ & 2 \\
\hline S3 & 2 & C338 & 2 \\
\hline S4 & 2 & D314 & 1 \\
\hline A.337 & 43 & D515 & 1 \\
\hline $\mathrm{A} 012$ & 2 & D493 & 1 \\
\hline A437 & 4 & D520 & 2 \\
\hline A.305 & 1 & D521 & 2 \\
\hline D506 & 1 & A 259 & 4 \\
\hline A138 & 8 & \begin{tabular}{|l|} 
A444 \\
\end{tabular} & 2 \\
\hline A.238 & 4 & B90MM & 1 \\
\hline $\mathrm{C} 331$ & & Prints & 1 \\
\hline
\end{tabular}

Figure 7 Preliminary Bill of Materials

Source: Own elaboration, (2020)

Knowing the whole process of the Pull Back Car assembly process allows us to optimize the preparation times. Therefore, in the first instance, the operations that make up this process are identified. This through a work study tool, the process flow diagram (Figure 8 Process flow diagram) as well as a format with visual aid for assembly operations (Figure 9 Component assembly operations format, with visual aid). 


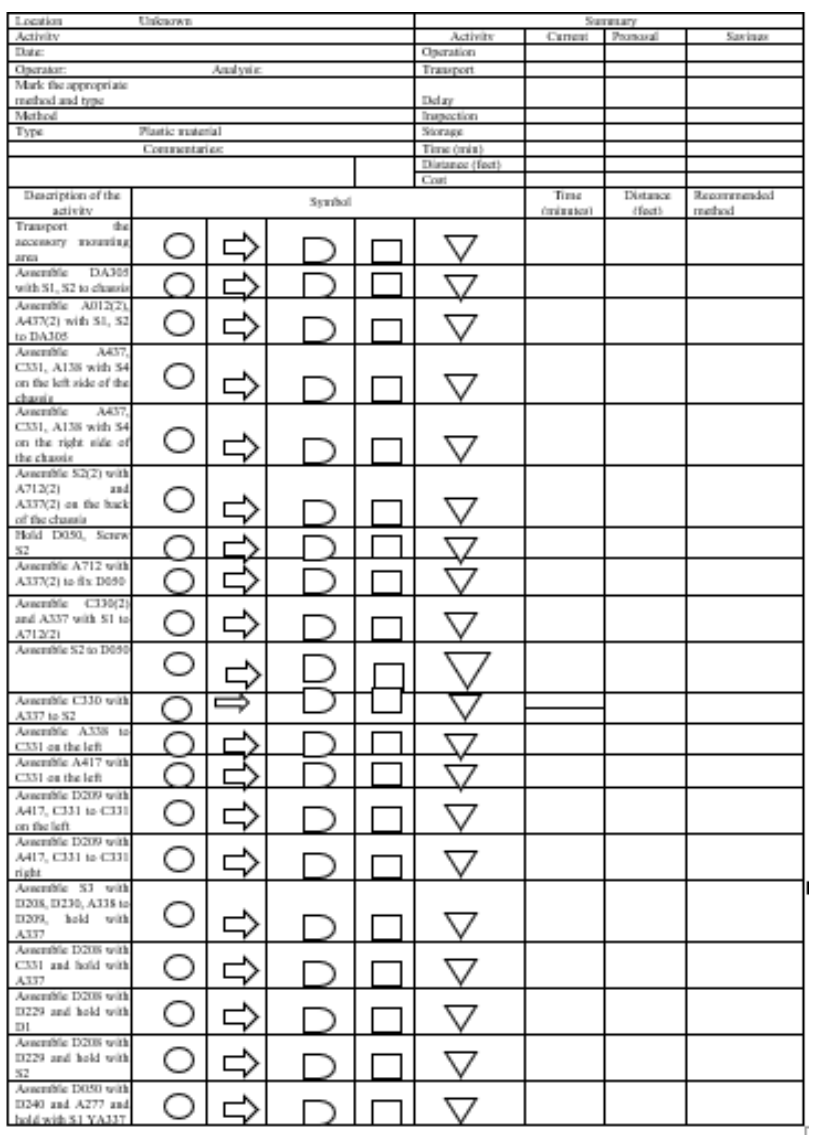

Figure 8 Process flow diagram Source: Own elaboration, (2020)

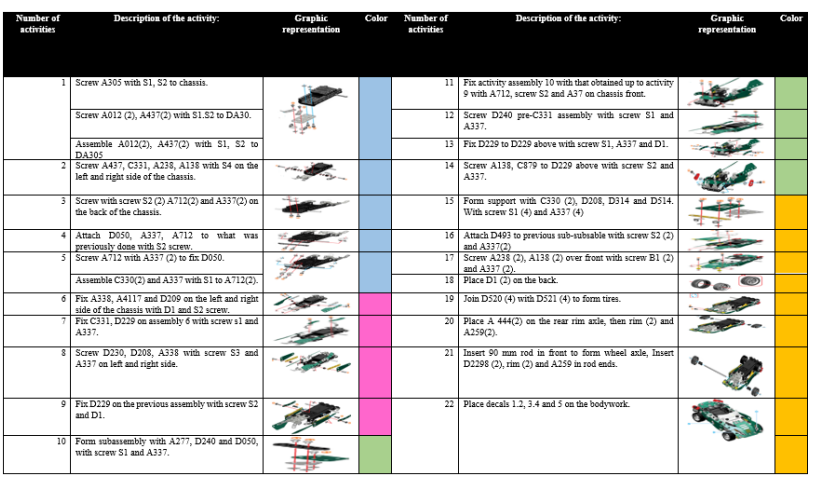

Figure 9 Component assembly operations format, with visual aid

Source: Own elaboration, (2020)

\section{Stage IV: Product and process validation}

For the validation of the Pull back car assembly process, a production program is established, consisting of the Master Production Plan and the Material Requirement Plan, these will allow to have control of both the production and the necessary materials.
Considering that the company has the capacity to produce 50 cars a day, it works six days a week, from Monday to Saturday with an 8-hour shift, and that cars are produced to order that usually arrive a week in advance; You can carry out the same Master Production Plan that will allow us to know the behavior of the delivery of orders. For its elaboration, a lot size of 50 units is established, with an initial inventory of 80 . The results are reflected in Table 1 Master Production Plan.

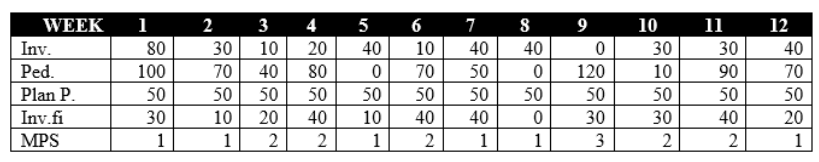

Table 1 Production master plan

Source: Own elaboration, (2020)

Now, pointing out the importance of a complete production plan, the Material Requirement Planning analysis is also added (See Table 2 Material Requirements Plan), which will allow us to have control over the raw materials of the product that is offers the customer. It is programmed with lots of 50 units with issuance every 2 weeks. This gives a total inventory cost after 10 weeks of $\$ 600$, a production cost of $\$ 430,000$, labor with $\$$ 103,200 . Resulting in a total of $\$ 533,800$.

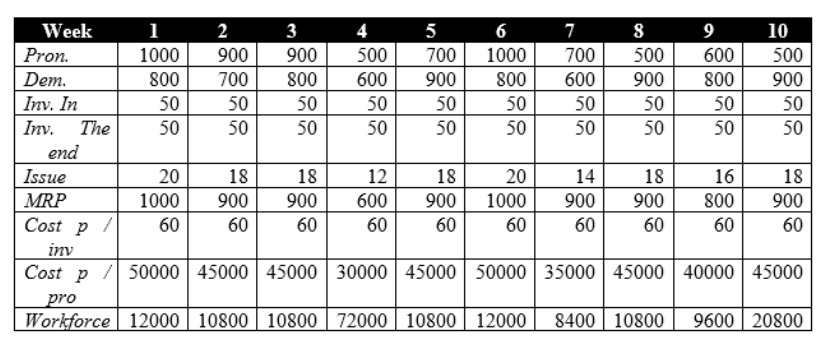

Table 2 Material Requirements Plan Source: Own elaboration, (2020)

Specifying the importance of having a plan that encourages customer satisfaction, both with the specifications of the product, as well as the service offered in the sale. The use of formats is proposed, such as FMEA (See Annex 1 Figure 10 FMEA Format) and a pre-launch control plan (Annex 2 Figure 11 Pre-launch control plan), this focusing on the assembly process, such as the inclusion of a check list for the review of a quality system (Note Annex 3 Figure 12 Check list for the review of the quality system and complaint format). 
Annexes

\section{Annex 1}

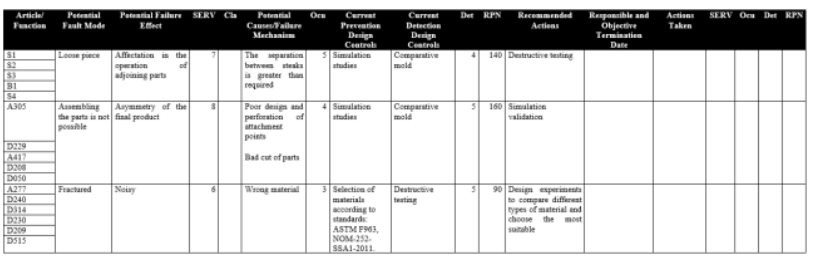

Figure 10 FMEA format

Source: Own elaboration, (2020)

\section{Annex 2}

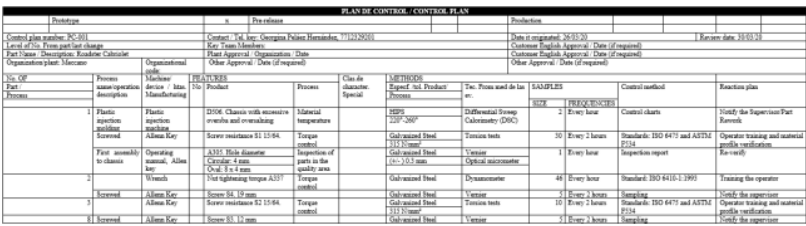

Figure 11 Pre-launch control plan

Source: Own elaboration, (2020)

\section{Annex 3}

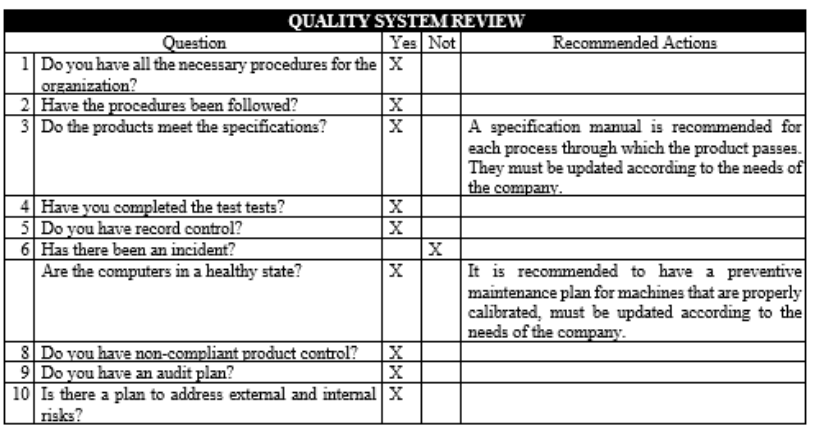

\section{Company name:
Date:}

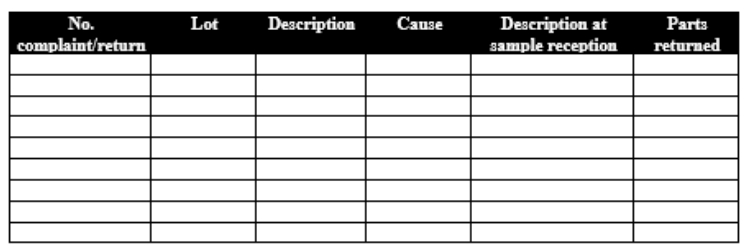

Figure 12 Check list to review the quality system and complaint format

Source: Own elaboration, (2020)

\section{Acknowledgement}

To the Instituto Tecnológico Superior de Huauchinango and the Academy of Industrial Engineering for the services provided for the development of this research.

\section{Conclusions}

We live in a global world, where every day there are more competitors who go through the same markets, so it is necessary to design and produce products for specific customers with specific needs and requirements. Do not think that once the customer knows the product he will value its many merits. Focusing the efforts of the organization towards the client, in all activities plays a vital role today. In particular, from the product design and development phase, in which product quality planning provides a consistent methodology that has proven its effectiveness for more than a decade.

In the town of Huauchinango Puebla, there is a great opportunity for the effective application of the APQP. Since, as has been shown, well applied it avoids future problems in the manufacture and performance of the product, shortens development times and clearly establishes the technical requirements of the product. Along with the mechanisms to comply with them. With the consequent improvement in the performance of processes and reduction of variability. The APQP is a systematic methodology that can be used not only by large companies, as many of them have already been doing, but also by small and medium-sized companies. local Pull Back Car assembly workshops that will follow the proposed APQP methodology, ensuring customer deliveries of orders on time and with the indicated quality.

\section{References}

Advanced product quality planning - APQP(1995). AIAG (Chrysler, Ford, GM).

Álzate (F). (2013). Sistema de Gestión de Calidad. Total. Recovered from: https://iso9001calidad-total.com/2013/06/19/como-hacer-larevision-del-sgc

ASTM F963 - 17. Especificación Estándar de Seguridad para el Consumidor para la Seguridad en los Juguetes. Recovered from: https://www.astm.org/Standards/F963-SP.htm

CIRS. (2008). CPSIA/HR4040. Chemical Inspection and Regulation Service. Recovered from: http://en.cirs-ck.com/services/toys/cpsia hr4040 
Feigenbaum, A. (1994). Control total de la calidad, tercera edición, CECSA, Cd. De México.

Heredera consultores. (2016). SISTEMA DE GESTIÓN DE LA CALIDAD. NORMA ISO 9001:2015. Heredera Consultores. Recovered from: http://hederaconsultores.com/docs/Checklist-auditoria-ISO-9001-2015.pdf

Ishikawa, K. (2000). ¿Qué es el control total de calidad? Tercera Edición. Norma, Bogota.

Juran, J.M. y Gryna, F.M. (1995). Análisis y planeación de la calidad, Tercera Edición, McGraw-Hill, Cd. de México.

NMX-E-082-CNCP-2010. Industria del plástico-resistencia a la tensión de materiales plásticos-método de ensayo. Recovered from: http://www.dof.gob.mx/normasOficiales/4169/s eeco/seeco.htm

NORMA Oficial Mexicana NOM-252-SSA12011, Salud ambiental. Juguetes y artículos escolares. Límites de biodisponibilidad de metales pesados. Especificaciones químicas y métodos de prueba. Recovered from: http://www.dof.gob.mx/normasOficiales/4704/s alud/salud.htm

Thisse, L.C (1998). Advanced quality planning: A guide for any organization. Quality Progress, Vol. 31, 2, pp. 73-78.

Veliayth, R. y Fitzgerald, E. (1998). Advanced Quality Planning: a common sense guide to AQP and APQP. ASQ Press, Milwaukee 